\title{
PENERAPAN METODE MIND MAPPING UNTUK MENINGKATKAN KETERAMPILAN MENULIS SURAT PRIBADI ISWA KELAS IIIA
}

\author{
A.M,Dwitha Evayanti ${ }^{1}$, Made Sumantri² \\ 1,2Jurusan Pendidikan Guru Sekolah Dasar, Fakultas IImu Pendidikan \\ Universitas Pendidikan Ganesha \\ Singaraja, Indonesia
}

e-mail: ayueva@gmail.com¹, madesumantri_pgsd@yahoo.co.id²

\begin{abstract}
Abstrak
Penelitian ini bertujuan untuk mengetahui peningkatan keterampilan menulis surat pribadi melalui penerapan metode mind mapping pada siswa kelas IIIA semester I tahun ajaran 2016-2017 SDN 1 Sumerta. Jenis penelitian ini adalah Penelitian Tindakan Kelas yang dirancang dalam 2 siklus. Subjek penelitian ini adalah seluruh siswa kelas IIIA semester 1 tahun ajaran 2016-2017 di SDN 1 Sumerta, yang berjumlah 40 orang siswa. Data dari penelitian ini diperoleh dengan menggunakan metode tes dengan bentuk instrumen berupa tes kinerja. Selanjutnya, data dianalisis dengan metode analisis deskriptif kuantitatif. Hasil penelitian menunjukkan bahwa terjadi peningkatan nilai keterampilan menulis surat pribadi siswa pada siklus I dengan persentase rata- rata sebesar $74,05 \%$ termasuk kriteria sedang, kemudian meningkat pada siklus II dengan persentase rata- rata $81,97 \%$ termasuk kriteria tinggi. Dengan demikian dapat disimpulkan bahwa keterampilan menulis surat pribadi siswa kelas IIIA semester I tahun ajaran 2016-2017 di SDN 1 Sumerta dapat ditingkatkan melalui penerapan metode mind mapping.
\end{abstract}

\section{Pendahuluan}

Kualitas Sumber Daya Manusia (SDM) yang baik akan mendukung kemajuan suatu bangsa. Pendidikan merupakan komponen penting untuk mewujudkan terbentuknya SDM yang berkualitas. Seperti yang tercantum dalam UU No. 20/ 2003 tentang Sistem Pendidikan Nasional Bab I Pasal 1 ayat 1 disebutkan "pendidikan adalah sebagai usaha sadar dan terencana untuk mewujudkan suasana belajar dan proses belajar agar peserta didik secara aktif mengembangkan potensi dirinya agar memiliki kekuatan spiritual keagamaan, pengendalian diri, kepribadian, kecerdasan, akhlak mulia, serta keterampilan yang diperlukan dirinya, masyarakat, bangsa, dan negara" (Ilyas, 2008: 40). Berdasarkan pengertian tersebut dapat diartikan bahwa melalui pendidikan, peserta didik dapat mengembangkan kemampuan atau potensi yang dimiliki untuk melahirkan pribadi yang beriman dan bertaqwa, memiliki kecerdasan, serta keterampilan yang memadai.

Usaha yang dapat dilakukan untuk meningkatkan mutu pendidikan, terutama di Indonesia adalah melalui pengoptimalan pelaksanaan pembelajaran baik di sekolah formal, informal, maupun nonformal. Kerja sama berbagai pihak sangat diperlukan dalam rangka tercapainya tujuan pembelajaran yang telah ditetapkan. Penguasaan kompetensi pada aspek sikap, pengetahuan, dan keterampilan menjadi pembuktian keberhasilan proses pembelajaran. Sikap, pengetahuan, dan keterampilan yang diperoleh siswa melalui proses belajar, nantinya akan sangat berguna sebagai bekal hidupnya di masyarakat.

Pada era globalisasi dalam bidang informasi seperti sekarang ini, masyarakat dituntut untuk terampil berkomunikasi dalam menerima ataupun menyampaikan ide dengan cepat dan tepat, baik dalam bahasa lisan maupun tulis. Komunikasi berlangsung secara efektif apabila para pelaku komunikasi yang bersangkutan 
menggunakan bahasa secara efektif pula. Masyarakat harus memiliki keterampilan berbahasa yang mumpuni agar bisa berkomunikasi secara efektif dan menghindari adanya kesalahpahaman.

Kenyataan yang terjadi saat ini adalah para siswa terasa enggan untuk mempelajari keterampilan berbahasa, dan bahkan banyak yang merasa kesulitan saat belajar keterampilan berbahasa terutama menulis. Setiap akan mengawali menulis, siswa terlihat kebingungan akan melakukan apa dan bahkan muncul kebosanan jika diminta untuk melakukan kegiatan menulis. Guru sebagai tenaga pendidik kurang menerapkan metode pembelajaran yang inovatif khususnya saat melaksanakan proses pembelajaran yang berkenaan dengan keterampilan menulis. Hal ini diperkuat dengan refleksi diri yang dilakukan, karena permasalahan ini muncul di kelas tempat peneliti mengajar. Refleksi diri dilakukan di kelas IIIA, SDN 1 Sumerta, pada saat itu, siswa sedang melakukan proses pembelajaran dengan tema Perkembangan Teknologi mata pelajaran Bahasa Indonesia, siswa dihadapkan dengan kegiatan menulis yaitu surat pribadi. Banyak siswa yang terlihat diam, tidak mengerjakan apa- apa. Pada saat ditanyakan, banyak siswa yang mengatakan bingung harus menulis apa dan ada yang mengatakan terlalu susah. Nilai keterampilan menulis surat pribadi siswa pun pada pembelajaran tersebut masih di bawah Kriteria Ketuntasan Minimal (KKM). KKM yang telah ditetapkan sekolah adalah $\geq 70$ pada predikat B. Sementara, siswa yang sudah mencapai nilai $\geq 70$ dalam keterampilan menulis surat pribadi kurang dari $70 \%$. Sebanyak 10 dari 40 siswa yang sudah mencapai nilai KKM dan sisanya 30 orang siswa belum mencapai KKM. Penyebab dari hal tersebut adalah guru belum menggunakan metode pembelajaran yang inovatif.

\section{Berdasarkan}

permasalahan tersebut, hendaknya dalam pembelajaran diterapkan metode pembelajaran yang inovatif, sehingga dapat lebih menarik dan menyenangkan untuk siswa. Guru dapat menerapkan salah satu metode pembelajaran inovatif dalam pembelajaran yang disesuaikan dengan materi yang akan dibelajarkan. Salah satu metode yang dapat diterapkan untuk meningkatkan keterampilan menulis siswa terutama dalam menulis surat pribadi adalah mind mapping.

Metode mind mapping adalah metode pembelajaran yang diterapkan dalam bentuk pemetaan pikiran. Mind mapping merupakan cara untuk menempatkan informasi ke dalam otak dan mengambilnya kembali keluar otak (Kurniasih dan Berlin, 2015).

Menurut Tony Buzan (2012),

Mind mapadalah cara mencatat yang kreatif, efektif, dan secara harfiah akan "memetakan" pikiran-pikiran kita." Sedangkan, menurut Andri Saleh (2009), "Mind map adalah diagram yang digunakan untuk menggambarkan sebuat tema, ide, atau gagasan utama dalam materi pelajaran." Jadi mind mapping ini dibuat oleh guru untuk menyampaikan materi pelajaran dan digunakan juga oleh siswa untuk pencatatanmateri pelajaran ataupun hasil diskusi kelompok.

Menurut Eric Jensen (dalam Rostikawati, 2008), peta pikiran (mind map) bertujuan membuat materi pelajaran terpola secara visual dan grafis yang akhirnya dapat membantu merekam, memperkuat, dan mengingat kembali informasi yang telah dipelajari. Dengan demikian pemetaan pikiran (mind mapping) merupakan suatu cara mencatat yang mengembangkan gaya belajar visual. Menurut Putra (2008) metode pencatatan menggunakan peta pikiran (mind map) memiliki keutamaan yaitu (1) tema utama terdefinisi secara sangat jelas karena dinyatakan di tengah; (2) level keutamaan informasi terindikasi secara lebih baik. Informasi yang memiliki kadar kepentingan lebih diletakkan dekat dengan tema utama; (3) hubungan antara masingmasing informasi secara mudah dapat segera dikenali, (4) lebih mudah dipahami dan ingat (sebagai akibat dari poin sebelumnya); (5) informasi baru setelahnya dapat segera digabungkan tanpa merusak keseluruhan peta pikiran, sehingga mempermudah proses revisiinformasi; (6) masing-masing peta pikran sangat unik, sehingga mempermudah proses pengingatan; (7) mempercepat proses pencatatan karena 
hanya meggunakan kata kunci. Sementara kekurangan metode pencatatan menggunakan peta pikiran (dalam Sape, 2012) antara lain adalah sebagai berikut: (1) hanya siswa yang aktif yang terlibat karena pada mind map merupakan catatan masing-masing siswa dan pembuatan atau penulisannya tidak dipatokkan bagaimana bentuknya oleh guru

Dengan mind mapping siswa dapat memetakan pikiran melalui simbol- simbol ataupun coretan- coretan yang berwarnawarni. "Pemetaan pikiran adalah cara kreatif bagi peserta didik secara individual untuk menghasilkan ide- ide, mencatat pelajaran, atau merencanakan penelitian baru" Silberman (2002).

Buzan (2013) mengemukakan bahwa langkah- langkah pelaksanaan metode mind mapping adalah sebagai berikut: 1) mulailah dari bagian tengah kertas kosong yang sisi panjangnya diletakkan mendatar, 2) gunakan gambar atau foto untuk ide sentral anda, 3) gunakan warna. Warna sama menariknya dengan gambar, 3) hubungkan cabangcabang utama ke gambar pusat dan hubungkan cabang- cabang tingkat dua dan tiga ke tingkat satu dan dua, dan seterusnya, 4) buatlah garis hubung yang melengkung, bukan garis lurus, 5) gunakan satu kata kunci untuk setiap garis. Kata kunci tunggal memberi lebih banyak daya dan fleksibilitas kepada mind map. 6) gunakan gambar, seperti gambar sentral, setiap gambar bermakna seribu kata, jadi bila kita hanya mempunyai 10 gambar di dalam mind map kita, mind map kita sudah setara dengan 10.000 kata catatan

Kelebihan dari metode mind mapping antara lain: 1) metode ini terbilang cukup cepat dimengerti dan cepat juga dalam menyelesaikan persoalan, 2) mind mapping terbukti dapat digunakan unttuk mengorganisasikan ideide yang muncul di kepala, 3) proses menggambar diagram bisa memunculkan ide- ide yang lain, 4) diagram yang sudah terbentuk bisa menjadi panduan untuk menulis (Kurniasih dan Berlin, 2015). Berkaitan dengan kegiatan menulis, penerapan prosedur mind mapping ini memang sangat menarik. Siswa bebas menuangkan ide- ide yang ada dalam pikiran mereka, dalam bentuk simbolsimbol atau gambar sehingga siswa dapat dengan mudah mengembangkan ide mereka ke dalam tulisan.

Mind map tidak hanya dapat membantu merencanakan apa yang akan ditulis, tetapi juga dapat membantu menuliskannya secara utuh dan dapat memeriksa kembali bahwa tulisan masih berada pada jalurnya (Buzan, 2013). Beberapa kelebihan yang telah dikemukakan tersebut, dapat disimpulkan bahwa mind mapping memiliki kelebihan yaitu cepat dimengerti, dapat memunculkan ide- ide baru, bahkan menjadi panduan untuk menulis agar tetap berada pada jalurnya.

Metode mind mapping tepat diterapkan untuk meningkatkan keterampilan menulis surat pribadi, karena siswa akan dibantu untuk merencanakan apa yang akan ditulis dan menghubungkan ide- ide atau gagasan, serta bagaimana memulai menulis. Keterampilan menulis merupakan salah satu keterampilan berbahasa yang produktif dan ekspresif yang dipergunakan untuk berkomunikasi secara tidak langsung dan tidak secara tatap muka dengan pihak lain (Tarigan, 2008).

Keterampilan menulis memiliki peran yang sangat penting bagi siswa karena dalam menyelesaikan tugasnya di kelas dengan baik, harus disertai dengan keterampilan menulis yang memadai. Tulisan yang baik akan diperoleh, jika kegiatan menulis dilakukan melalui beberapa tahap penulisan, yaitu tahap prapenulisan, tahap penulisan, dan tahap revisi. Penjabaran setiap tahapan adalah sebagai berikut: 1) Tahap prapenulisan (persiapan), tahap ini ketika pembelajar menyiapkan diri, mengumpulkan informasi, merumuskan masalah, menentukan fokus, mengolah informasi, menarik tafsiran dan inferensi terhadap realitas yang dihadapinya, berdiskusi, membaca, mengamati, dan lain-lain yang memperkaya masukan kognitifnya yang akan diproses selanjutnya. Pada tahap prapenulisan ini terdapat aktivitas memilih topik, menetapkan tujuan dan sasaran, mengumpulkan bahan dan informasi yang diperlukan, serta mengorganisasikan ide 
atau gagasan dalam bentuk kerangka karangan. 2) Tahap penulisan, mengembangkan butir demi butir ide yang terdapat dalam kerangka karangan, dengan memanfaatkan bahan atau informasi yang telah dipilih dan dikumpulkan. 3) Tahap pascapenulisan, tahap penghalusan dan penyempurnaan buram yang dihasilkan. Kegiatannya terdiri atas penyuntingan dan perbaikan (revisi). Penyuntingaan adalah pemeriksaan dan perbaikan unsur mekanik karangan seperti ejaan, pungtuasi, diksi, pengalimatan, pengalineaan, gaya bahasa, pencatatan kepustakaan, dan konvensi penulisan lainnya. Adapun revisi atau perbaikan lebih mengarah pada pemeriksaan dan perbaikan isi karangan (Dalman, 2015).

Alat komunikasi tertulis yang sering digunakan adalah surat. Dengan surat seseorang dapat menyampaikan ide atau gagasannya yang tidak dapat disampaikan secara lisan. "Surat ialah sarana untuk menyampaikan pikiran, isi hati, maksud, atau kehendak pada orang lain melalui bahasa tulis dengan menggunakan kertas sebagai medianya" (Dalman, 2015). Jika ditinjau dari sifat isinya, surat adalah jenis karangan paparan karena di dalamnya si pengirim mengemukakan maksud dan tujuan atau menjelaskan apa yang dipikirkan dan dirasakan (Darmawati, 2007). Jadi surat merupakan alat atau sarana komunikasi untuk menyampaikan pikiran, maksud dari si pengirim secara tertulis.

Terdapat beberapa jenis surat, yang secara umum dikelompokkan ke dalam 3 jenis yaitu surat dinas, surat niaga, dan surat pribadi. Sebagai langkah awal untuk mengasah keterampilan menulis siswa terutama menulis surat, dapat dimulai dengan menulis surat yang ditujukan untuk sahabat, teman, atau keluarga. Surat yang ditulis yang sifatnya tidak resmi ini disebut dengan surat pribadi. Surat pribadi adalah surat yang ditulis untuk kepentingan pribadi bukan untuk suatu lembaga atau organisasi (Dalman, 2015).

Surat pribadi tidak menggunakan bahasa yang resmi sehingga surat pribadi dikatakan bersifat informal (Maharani, 2007). Surat yang sangat lekat dengan kegiatan masyarakat dalam berkomunikasi adalah surat pribadi. Surat pribadi akan menjadi materi yang akan mampu membangunkan daya kreatifitas dalam menuangkan ide-ide atau pengalaman serta dapat mengasah keterampilan menulis peserta didik. Selain itu hal-hal yang berhubungan dengan surat pribadi misalnya format yang tepat, atau bahasa yang digunakan sangatlah penting agar dapat membuat surat dengan baik dan benar.

Surat pribadi adalah surat yang dibuat oleh seseorang atas nama diri pribadinya sendiri (Arifin, 1987). Oleh sebab itu, surat ini dapat berupa surat keluarga, setengah resmi, dan terbuka. Karena sifatnya pribadi, dalam surat pribadi terasa hubungan santai dan mesra. Surat pribadi adalah bentuk komunikasi tulis (surat- menyurat) yang dilakukan oleh seseorang kepada orang lain sebagai pribadi, bukan sebagai wakil atau utusan yang berkaitan dengan kelembagaan/kedinasan/resmi (Trianto, 2007). Berdasarkan uraian tersebut, surat pribadi merupakan surat tidak resmi yang ditulis untuk kepentingan pribadi dan bersifat informal.

Ciri-ciri yang terdapat dalam surat pribadi yaitu (1) tidak mempergunakan gaya penulisan surat resmi, misalnya saja tidak mempergunakan nomor surat, lampiran, atau lampiran sebagaimana surat dinas atau surat resmi, (2) kalimat dalam surat pribadi lebih bersifat kekeluargaan atau persaudaraan, (3) dengan demikian gaya bahasa yang dipergunakan tidak terlalu formal atau resmi, (4) salam pembuka lebih bervariasi sesuai dengan selera pengirim atau penulis surat, (5) format kertas surat tidak mempergunakan kop surat sebagaimana halnya pada surat dinas, (7) tidak mengenal bentuk penulisan yang mempergunakan tembusan atau landasan, (8) secara etis jumlah lembar surat yang ditulis tidak terlalu dibatasi. Sedangkan pada surat dinas sebagai gantinya menggunakan jenis lampiran (Yasin, 2009).

Nurkholis dan Mafrukhi (2007) mengemukakan bagian surat pribadi terdiri atas: 1) Lokasi dan tanggal penulisan surat, tanggal surat dalam penulisan tanggal surat sebaiknya tanggal, bulan, 
dan tahun ditulis lengkap, jangan disingkat. Penyingkatan tanggal dan bulan surat sering menimbulkan kesalahpahaman dan dirasakan kurang santun, tanggal surat ini ditulis untuk menunjukkan kapan surat itu dikirim bukan kapan surat itu dibuat. Contoh: Surabaya, 25 Agustus 2007.) Alamat surat, alamat surat pengiriman dan penerimaan surat dapat berjalan dengan lancar jika alamat ditulis dengan jelas. Biasanya sebuah surat mempunyai alamat surat dua macam, yaitu alamat yang ditulis pada kertas surat dan alamat luar yang ditulis pada sampul surat. Contoh penulisan alamat surat: Sahabatku Metana Umi Sakha Rida Gunungpati, Semarang. 3) Salam pembuka, salam pembuka suatu surat digunakan sebagai kesatuan berbahasa tulis. Salam pembuka dapat digunakan sesuai dengan keperluan penulisan surat. Contoh penggunaan salam pembuka: Dengan hormat, Bapak/ibu yang tercinta. 4) Salam rindu/persahabatan/sayang, salam pembuka jenis pertama, kedua, dan ketiga merupakan salam pembuka yang paling umum dan biasa dipakai dalam surat pribadi. Yang pertama biasanya digunakan untuk surat yang setengah resmi, misalnya surat izin tidak masuk sekolah, dan yang kedua dan ketiga biasanya di gunakan untuk kerabat dan keluarga. 5) Isi surat, isi surat adalah bagian surat yang digunakan untuk menyatakan berita, atau sesuatu yang ingin dinyatakan dalam surat tersebut. Bagian isi surat biasanya berisi atau terdiri atas: paragraf pembuka, paragraf isi, paragraf penutup. Paragraf pembuka ialah bagian surat yang berfungsi sebagai pengantar pembaca kepada inti pokok surat. Dengan kata lain paragraf pembuka berguna sebagai penuntun jalan pikiran pembaca kepada masalah yang akan dibicarakan dalam uraian inti surat. Paragraf isi ini memuat sesuatu yang akan disampaikan, diberitahukan, dinyatakan atau dimintakan kepada penerima surat. Paragraf penutup berfungsi untuk menutup inti surat. Dapat pula dinyatakan bahwa paragraf penutup ini dianggap sebagai kunci isi surat atau penugasan isi surat. Oleh karena paragraf tersebut isinya selain mangandung harapan juga berisi ucapan terima kasih kepada penerima surat. 6) Salam penutup, salam penutup sebuah surat dapat digunakan untuk menunjukkan rasa hormat dan rasa keakraban pengirim surat terhadap penerima surat. 7) Nama dan tanda tangan penulis surat, nama dan tanda tangan pengirim surat ditulis di bawah salam penutup. Dalam penulisan nama pengirim tidak harus menggunakan huruf kapital tetapi menggunakan huruf awal huruf kapital pada setiap nama.

Berkaitan dengan penelitian ini, kegiatan menulis surat pribadi dapat dijadikan sebagai langkah awal dalam melatih keterampilan menulis siswa. Untuk meningkatkan keterampilan menulis siswa terutama dalam menulis surat pribadi, mind mapping merupakan metode pembelajaran yang tepat untuk digunakan. Mind mapping dapat membantu siswa merencanakan apa yang akan ditulis Metode pembelajaran ini akan memudahkan siswa untuk menulis apa yang akan ditulis. Hal ini dapat diartikan penerapan metode mind mapping dapat membantu siswa meningkatkan keterampilan menulis surat pribadi. Seperti yang dikemukakan oleh Buzan dalam bukunya yaitu The Ultimate Book of Mind Maps bahwa mind map tidak hanya dapat membantu merencanakan apa yang akan ditulis, tetapi juga berguna ketika ingin menuliskannya secara utuh (Buzan, 2013).

"Saat memetakan pikiran dan membiarkan gagasan dan pemikiran Anda menyebar ke seluruh halaman. Anda akan mencapai suatu tahap saat Anda tiba tiba 'tahu' hal yang ingin Anda tulis" (Hernowo, 2004). Dengan demikian, pemetaan pikiran adalah cara yang sangat baik untuk menghasilkan dan menata gagasan sebelum menulis (Wycoff, 2005).

Hasil penelitian yang relevan yang mendukung pernyataan tersebut di antaranya adalah penelitian yang telah dilakukan oleh Santihani (2016) di SD No. 1 Dalung dengan menerapkan pendekatan saintifik berbantuan mind mapping dapat meningkatkan penguasaan kompetensi keterampian menulis dalam bahasa Indonesia tema Sejarah Peradaban Indonesia siswa kelas VA tahun ajaran 2015- 2016. Hasil penelitian yang 
memperlihatkan adanya peningkatan yaitu pada siklus II persentase keberhasilan sudah melebihi $80 \%$ siswa mencapai KKM $\geq 70$ pada predikat B. Selanjutnya, hasil penelitian yang telah dilaksanakan oleh Wulandari (2016) yang menunjukkan peningkatan penguasaan kompetensi keterampilan menulis siswa kelas IVA SDN 29 Pemecutan, dengan persentase keberhasilan rata- rata $75 \%$ pada siklus II, dengan kategori (A-).

Melalui pemetaan pikiran, segala ide yang ada di otak dituangkan ke dalam simbol- simbol dan kata kunci, maka akan memudahkan untuk menulis. Sehingga apa yang akan ditulis sudah terlihat pada mind map yang telah dibuat. Berdasarkan pemaparan tersebut, melalui penerapan metode mind mapping dapat membantu siswa untuk meningkatkan keterampilan menulis surat pribadi siswa kelas IIIA SDN 1 Sumerta tahun ajaran 2016-2017.

\section{Metode}

Penelitian ini termasuk ke dalam Penelitian Tindakan Kelas (PTK). PTK merupakan penelitian yang dilakukan oleh guru di dalam kelas sendiri melalui refleksi diri dengan tujuan memperbaiki kinerja sebagai guru, sehingga hasil belajar siswa menjadi meningkat (Wardhani, 2008

Subjek dalam penelitian ini adalah siswa kelas IIIA SDN 1 Sumerta pada semester I, tahun ajaran 2016-2017 yang berjumlah 40 siswa. Sedangkan yang menjadi objek penelitian adalah keterampilan menulis surat pribadi dengan diterapkannya metode mind mapping.

Penelitian dirancang ke dalam 2 siklus. Tahapan per siklus dimulai dari perencanaan tindakan, pelaksanaan tindakan, observasi (pengamatan), dan refleksi. Pada saat merencanakan tindakan yang dilakukan adalah menyusun Rencana Pelaksanaan Pembelajaran (RPP) sesuai dengan tema yang akan dibelajarkan, menyediakan sumber belajar berupa: buku tematik tema "Peduli Lingkungan Sosial" dan menyiapkan media pembelajaraan berupa contoh gambar mind mapping, membuat kisi- kisi tes akhir siklus I beserta tes akhir siklus I sesuai dengan materi pembelajaran, dan membuat jadwal pelaksanaan tindakan.
Tindakan untuk siklus I dilaksanakan sebanyak 3 kali pertemuan untuk menerapkan metode mind mapping pada keterampilan menulis surat pribadi dan 1 kali pertemuan untuk memberikan tes akhir siklus I. Penjabaran dari tahap pelaksanaan adalah pada awal pembelajaran, guru memberikan apersepsi, guru menyampaikan materi dan tujuan pembelajaran, siswa diberikan penjelasan dan contoh mengenai mind mapping oleh guru, siswa membuat mind mapping surat tanggapan pribadi sesuai pemahamannya, siswa menunjukkan mind mapping yang dibuat di depan kelas, siswa berlatih menulis surat tanggapan pribadi berdasarkan mind mapping yang telah dibuat, Hasil pekerjaan siswa dinilai oleh guru, guru memberikan penguatan positif, kegiatan guru dan siswa diakhiri dengan menyebutkan hal-hal yang sudah dipelajari pada hari itu, siswa bersama guru menyimpulkan pelajaran, guru menutup pembelajaran dengan berdoa dan salam. Pada pertemuan kedua dan ketiga sama seperti kegiatan di pertemuan pertama. Dilanjutkan dengan pertemuan keempat, yaitu pemberian tes akhir siklus I sesuai dengan kisi- kisi dan instrumen yang telah disiapkan.

Kemudian dilanjutkan dengan observasi. Dalam observasi, dilakukan dengan mengumpulkan informasi, berupa hal- hal penting dan kekurangankekurangan yang menjadi hambatan selama pelaksanaan tindakan. Selanjutnya akan menjadi masukkan saat kegiatan refleksi. Refleksi dilakukan dengan mencarikan solusi untuk kendalakendala yang dihadapi. Hasil dari kegiatan ini berupa informasi yang digunakan sebagai dasar untuk merancang kegiatan yang dilaksanakan pada siklus II. Uraian kegiatan yang dilaksanakan pada tiap tahap untuk siklus II pada dasarnya sama seperti uraian kegiatan yang dilaksanakan pada siklus I yaitu perencanaan, pelaksanaan, observasi, dan refleksi. Setiap tahap dapat mengalami perubahan sesuai hasil yang diperoleh pada siklus sebelumnya.

Pada perencanaan tindakan siklus II, yang dilakukan adalah mengevaluasi hasil refleksi, mendiskusikan, dan mencari upaya perbaikan untuk diterapkan pada 
pembelajaran berikutnya. Kemudian mendata masalah dan kendala yang dihadapi saat pembelajaran, dilanjutkan dengan merancang perbaikan berdasarkan refleksi siklus I.

Selanjutnya, tidak jauh berbeda dengan pelaksanaan tindakan pada siklus I, tahap pelaksanaan tindakan pada siklus II, dilaksanakan pembelajaran berdasarkan RPP yang telah disusun pada tahap perencanaan dengan menerapkan metode mind mapping. Pelaksanaan tindakan sebagai berikut: 1) pada awal pembelajaran, guru memberikan apersepsi, 2) guru menyampaikan materi dan tujuan pembelajaran, 3) siswa diberikan penjelasan dan contoh mengenai mind mapping oleh guru, 4) siswa membuat mind mapping surat tanggapan pribadi sesuai pemahamannya, 5) siswa menunjukkan mind mapping yang dibuat di depan kelas, 6) siswa berlatih menulis surat tanggapan pribadi berdasarkan mind mapping yang telah dibuat, 7) hasil pekerjaan siswa dinilai oleh guru, 8) guru memberikan penguatan positif, 9) kegiatan guru dan siswa diakhiri dengan menyebutkan hal-hal yang sudah dipelajari pada hari itu, 10) siswa bersama guru menyimpulkan pelajaran, dan 11) guru menutup pembelajaran dengan berdoa dan salam.

Pada pertemuan kedua dan ketiga sama seperti kegiatan di pertemuan pertama. Dilanjutkan dengan pertemuan keempat, yaitu pemberian tes akhir siklus II sesuai dengan kisi- kisi dan instrumen yang telah disiapkan.

Berikutnya observasi, pada tahap ini dilakukan pengamatan terhadap penerapan metode mind mapping, melalui pencatatan atas perubahan yang terjadi selama tindakan. Dilanjutkan dengan melakukan diskusi membahas masalah yang dihadapi saat pembelajaran. Selanjutnya melakukan kegiatan refleksi siklus II, dilakukan hal- hal berikut ini yaitu: merefleksikan keterampilan menulis surat pribadi siswa dengan penerapan metode mind mapping, dan menganalisis temuan dan hasil akhir penelitian. Jika dalam siklus II belum mencapai indikator keberhasilan yang ditetapkan, maka akan dilanjutkan pada siklus III. Dan jika sudah mencapai indikator keberhasilan, tindakan dihentikan sampai di siklus II saja.

Dalam penelitian ini, metode yang digunakan untuk pengumpulan data adalah metode tes. Tes merupakan salah satu cara untuk menaksir besarnya tingkat kemampuan manusia secara tidak langsung, yaitu melalui respons seseorang terhadap sejumlah stimulus atau pertanyaan (Rasyid dan Mansur, 2008). Tes yang digunakan dalam penelitian ini adalah tes tertulis dalam bentuk tes keterampilan menulis. Tes digunakan untuk mengumpulkan data nilai keterampilan menulis surat pribadi siswa. Untuk memperoleh data yang akurat dalam penelitian ini menggunakan instrumen. Instrumen penelitian adalah suatu alat yang digunakan untuk mengukur fenomena alam maupun sosial yang diamati (Sugiyono, 2014).

Dalam penelitian ini instrumen yang digunakan untuk mengukur hasil belajar siswa adalah instrumen tes kinerja menulis surat pribadi. Sebuah tes dikatakan valid jika tes dapat mengukur dan mampu menyerap objek yang hendak diukur ketepatan alat ukur dengan hal yang diukur (Agung, 2010). Untuk mengetahui bahwa tes yang digunakan dalam penelitian ini dapat dikatakan valid, alat tes tersebut dibuatkan kisi- kisinya dan juga dikonsultasikan dengan guru Bahasa Indonesia di sekolah tempat penelitian dilakukan.

Data yang telah terkumpul akan dianalisis dengan teknik analisis deskriptif kuantitatif. Adapun langkah-langkah analisisnya sebagai berikut: mengumpulkan hasil kerja siswa, menghitung nilai individu siswa, dan persentase rata- rata nilai keterampilan menulis siswa.

Indikator keberhasilan untuk penelitian ini adalah persentase rata- rata nilai keterampilan menulis surat pribadi siswa ditetapkan yaitu $80 \%$ pada kategori tinggi. Apabila indikator keberhasilan tercapai maka penelitian dihentikan dan akan dijadikan simpulan dan pembahasan bahwa siklus tersebut telah tercapai. 


\section{Hasil Dan Pembahasan}

Data yang dikumpulkan dalam penelitian ini adalah data mengenai keterampilan menulis surat pribadi, yang terdiri atas data siklus I dan data siklus II. Persentase rata-rata nilai keterampilan menulis surat pribadi siswa kelas IIIA di SDN 1 Sumerta pada siklus I sebesar $74,05 \%$. Data tersebut diperoleh, setelah dilakukannya tindakan dengan metode mind mapping pada keterampilan menulis surat pribadi siswa kelas IIIA SDN 1 Sumerta pada siklus I Selama proses tindakan pembelajaran pada siklus I terdapat kendala-kendala yang timbul yang harus ditindaklanjuti, adapun kendala-kendala yang timbul pada proses pembelajaran siklus I dapat dijabarkan sebagai berikut: a. siswa belum terbiasa mengikuti pembelajaran dengan metode mind mapping, b. siswa belum paham menuangkan ide- ide mereka dalam mind mapping, c. kurang sesuainya surat pribadi yang ditulis dengan mind mapping yang dibuat.

Menindaklanjuti permasalahan yang muncul pada siklus I, maka hal-hal yang dilakukan pada siklus II sebagai berikut: a. siswa diberi pengarahan dan penekanan mengenai metode pembelajaran yang diterapkan agar siswa memiliki kesiapan dalam melakukan kegiatan pembelajaran dengan menggunakan metode mind mapping, $\mathrm{b}$. siswa diberikan contoh yang lebih jelas dan dilakukan dalam kelompok, agar siswa bisa saling bertukar inspirasi dalam membuat mind mapping, c. siswa diberikan bimbingan saat menuangkan mind mapping yang dibuat dalam penulisan surat pribadi.

Persentase rata-rata nilai keterampilan menulis surat pribadi siswa kelas IIIA di SDN 1 Sumerta pada siklus II sebesar $81,97 \%$. Berdasarkan hasil tindakan siklus II menunjukkan nilai keterampilan menulis surat pribadi siswa yang mencapai indikator keberhasilan yang ditetapkan maka siklus berikutnya tidak dilanjutkan lagi.

Pada pelaksanaan tindakan di siklus II siswa juga sudah bisa membuat mind mapping dengan tepat sesuai dengan ide- ide sebagai dasar menulis surat pribadi, siswa juga sudah bisa menulis surat pribadi dengan benar, dan siswa menjadi lebih aktif dan kreatif untuk mengeluarkan ide- idenya dalam bentuk simbol maupun tulisan yang selanjutnya dikembangkan dalam menulis surat pribadi.

Hasil penelitian yang diperoleh dari siklus I menunjukkan bahwa setelah diterapkannya metode mind mapping keterampilan menulis surat pribadi siswa mengalami peningkatan. Sebanyak 25 orang siswa mendapatkan nilai di atas 70 dengan persentase rata- rata nilai keterampilan menulis surat pribadi siswa sebesar 74,05\%. Keterampilan dalam menuliskan kelengkapan isi surat pribadi dan struktur kalimat sudah mulai dikuasai oleh beberapa siswa, melalui penerapan metode mind mapping.

Penelitian yang dilakukan sudah dikatakan berhasil jika sudah memenuhi kriteria keberhasilan yang ditetapkan. Berdasarkan persentase rata- rata nilai keterampilan menulis siswa pada siklus I diperoleh sebesar $74,05 \%$, hasil tersebut masih di bawah indikator keberhasilan yang telah ditetapkan yaitu $80 \%$, untuk itu, penelitian dilanjutkan pada siklus II. Pelaksanaan tindakan pada siklus II, pada dasarnya sama dengan pelaksanaan tindakan pada siklus I yaitu dengan menerapkan metode mind mapping. Permasalahan yang ditemui pada siklus I telah direfleksi, sebelum dilakukan penelitian pada siklus II. Permasalahan tersebut di antaranya: (1) siswa belum terbiasa mengikuti pembelajaran dengan metode mind mapping, (2) siswa belum paham menuangkan ide- ide mereka dalam mind mapping, dan (3) kurang sesuainya surat pribadi yang ditulis dengan mind mapping yang dibuat.

Beberapa kekurangan dalam pelaksanaan pada siklus I, menyebabkan belum tercapainya indikator keberhasilan yang ditetapkan, untuk itu dilanjutkan dengan pelaksanaan tindakan pada siklus II. Menindaklanjuti kekurangan pada siklus I, maka ada beberapa perbaikan yang dilakukan yaitu (1) siswa diberi pengarahan dan penekanan mengenai metode pembelajaran yang diterapkan agar siswa memiliki kesiapan dalam melakukan kegiatan pembelajaran dengan menggunakan metode mind mapping (2) 
siswa diberikan contoh yang lebih jelas dalam pembuatan mind mapping (3) siswa diberikan bimbingan saat menuangkan mind mapping yang dibuat dalam penulisan surat pribadi.

Berdasarkan data hasil penelitian siklus II, dapat diketahui bahwa persentase rata- rata nilai keterampilan menulis siswa pada siklus II sebesar $81,97 \%$. Pelaksanaan pembelajaran pada siklus II mengalami peningkatan yang lebih baik dibandingkan dengan siklus I. Pada pelaksanaan tindakan di siklus II siswa juga sudah bisa membuat mind mapping dengan tepat sesuai dengan ideide sebagai dasar menulis surat pribadi, siswa juga sudah bisa menulis surat pribadi secara terstruktur, begitu pula dengan kalimat yang sudah ditulis dengan benar, dan siswa menjadi lebih aktif dan kreatif untuk mengekspresikan ide- idenya dalam bentuk simbol maupun tulisan yang selanjutnya dikembangkan dalam menulis surat pribadi.

Pemetaan pikiran (mind mapping) adalah cara yang sangat baik untuk menghasilkan dan menata gagasan sebelum menulis (Wycoff, 2005). Melalui mind mapping, siswa dapat lebih mudah menuliskan apa yang akan ditulis. Hal ini juga didukung dengan hasil penelitian Santihani (2016) di SD No. 1 Dalung dengan menerapkan pendekatan saintifik berbantuan mind mapping dapat meningkatkan penguasaan kompetensi keterampian menulis dalam bahasa Indonesia tema Sejarah Peradaban Indonesia siswa kelas VA tahun ajaran 2015- 2016. Hasil penelitian yang memperlihatkan adanya peningkatan yaitu pada siklus II persentase keberhasilan sudah melebihi $80 \%$ siswa mencapai KKM $\geq 70$ pada predikat B. Penelitian yang dilaksanakan oleh Santihani dengan hasil penelitian ini sama- sama terdapat peningkatan yang signifikan dalam hasil penelitiannya. Hanya saja penelitian ini lebih terfokus pada penulisan surat pribadi. Maka dapat dikemukakan bahwa temuan ini (2017) memperkuat simpulan Santihani (2016).

Berdasarkan data penelitian tersebut, dengan demikian, penerapan metode mind mapping berhasil meningkatkan keterampilan menulis surat pribadi siswa kelas IIIA SD Negeri 1 Sumerta. Untuk itu, penelitian dihentikan pada siklus II, karena telah mencapai indikator keberhasilan.

\section{Simpulan Dan Saran}

Berdasarkan hasil analisis data dan pembahasan yang disajikan pada bab sebelumnya diperoleh jawaban atas rumusan masalah dalam penelitian ini, yaitu penerapan metode mind mapping dapat meningkatkan keterampilan menulis surat pribadi siswa kelas IIIA SDN 1 Sumerta. Hal ini dibuktikan dengan adanya peningkatan nilai yang dapat dilihat dari persentase rata- rata nilai keterampilan menulis surat pribadi siswa, yaitu pada pada siklus I sebesar $74,05 \%$, dan pada siklus II sebesar $81,97 \%$.

Hasil penelitian tersebut, telah menunjukkan adanya peningkatan yang signifikan dalam keterampilan menulis surat pribadi. Dapat disimpulkan bahwa keterampilan menulis surat pribadi siswa kelas IIIA SDN 1 Sumerta dapat ditingkatkan melalui penerapan metode mind mapping.

Berdasarkan hasil penelitian penerapan metode mind mapping guna meningkatkan keterampilan menulis surat pribadi siswa, disampaikan beberapa saran untuk pihak-pihak yang terkait. Saran yang dapat disampaikan untuk para siswa adalah untuk memudahkan dalam mengingat, mengembangkan kemampuan berpikir, dan mengembangkan kreativitas dalam menulis terutama menulis surat pribadi, siswa dapat membuat mind mapping sebelum melakukan kegiatan menulis.

Selanjutnya, sebagai seorang guru
yang profesional, tentunya ingin meningkatkan kualitas peserta didik. Untuk itu guru disarankan agar lebih banyak menerapkan metode- metode pembelajaran yang inovatif. Dalam penelitian ini, salah satu metode inovatif yang dapat diterapkan adalah metode mind mapping, terutama dalam kegiatan menulis. Sedangkan untuk sekolah, disarankan agar senantiasa mengembangkan atau bahkan menciptakan metode pembelajaran inovatif, karena telah terbukti mampu meningkatkan kualitas hasil belajar siswa. 
Khususnya untuk metode mind mapping ini, pihak sekolah dapat menerapkannya pada mata pelajaran yang lain.

Peneliti lain yang akan meneliti permasalahan yang serupa, dapat menggunakan metode mind mapping untuk memecahkan masalah tersebut. Bahkan dapat menemukan metode lain atau menggunakan metode ini dalam permasalahan lain yang muncul di kelas.

\section{Daftar Pustaka}

Agung, A.A. Gede. 2010. Penelitian Tindakan Kelas (Teori dan Analisis Data dalam PTK). Singaraja: FIP Undiksha.

Arifin, Syamsir. 1987. Pedoman Penulisan Surat Menyurat Indonesia. Padang: Angkasa Raya.

Buzan, Tony. 2013. Buku Pintar Mind Map. Terjemahan Susi Purwoko. The Ultimate Book of Mind Maps. PT. Jakarta: Gramedia Pustaka Utama.

Dalman, H. 2015. Keterampilan Menulis. Jakarta: PT. Raja Grafindo Persada.

Darmawati, Uti. 2007. Surat- surat Pribadi. Klaten: PT. Intan Pariwara.

Hernowo (ed.).2004. Cara Cepat nsn Bermanfaat untuk Merangsang Munculnya Potensi Menulis. Terjemahan Eva Y. Nukman. Quantum Writing. Bandung: Penerbit MLC.

Ilyas, Ismail. 2008. IImu Pendidikan Praktis. Jakarta: Ganeca Exact.

Kurniasih, Imas dan Berlin. 2015. Ragam Pengembangan Model Pembelajaran. Kata Pena.

Maharani, Ida. 2007. Bagaimana Menulis dengan Efektif. Yogyakarta: Citra Aji Parama.

Nurkholis, Hanif dan Mafrukhi. 2007. Saya Senang Berbahasa Indonesia. Jakarta: Erlangga.

Putra, Yovan P. 2008. Memori dan Pembelajaran Efektif.Bandung: Yrama Widya.Sape, Mirfan. 2012. Model Pembelajaran Mind
Mapping.

(Online).

(http://mirfansape.blogspot.com/20

12/12/model-pembelajaran-mind

mapping.html. Dikunjungi tanggal 19 Desember 2012)

Rasyid, Harun, Drs. dan Drs. Mansur, M.Pd. 2008. Penilaian Hasil Belajar. Bandung: CV Wacana Prima.

Rostikawati, R. Teti. 2008. Mind Mapping dalam Metode Quantum Learning Pengaruhnya Terhadap Prestasi Belajar dan Kreatifitas Siswa. Fakultas Keguruan dan IImu Pendidikan - Universitas Pakuan. (Online).

(http://etalaseilmu.wordpress.com/ 2009/10/02/mind-mapping-metodequantum-learning/. Dikunjungi tanggal 19 Juli 2012).

Saleh Andri. (2009).Kreatif Mengajar Dengan Mind Map.Bogor: CV Regina

Santihani, Ni Wayan Rosita. 2016. Penerapan Pendekatan Saintifik Berbantuan Mind Mapping untuk Meningkatkan Penguasaan Kompetensi Keterampilan Menulis dalam Bahasa Indonesia Kelas VA SD No. 1 Dalung Tahun 2015/2016. Skripsi (tidak diterbitkan). Jurusan Pendidikan Guru Sekolah Dasar, FIP Undiksha.

Silberman, Mel. 2002. Pembelajaran Aktif. Terjemahan Sarjuli, dkk. Active Learning. $1996 . \quad$ Yogyakarta: Pustaka Insan Madani.

Sugiyono. 2014. Metode Penelitian Pendidikan. Bandung: Alfabeta.

Tarigan, Henry Guntur. 2008. Menulis Sebagai Suatu Keterampilan Berbahasa. Bandung: Angkasa.

Trianto, Agus. 2007. Pembahasan Tuntas Kompetensi Bahasa Indonesia. Jakarta: Esis

Wardhani, IGK. 2008. Penelitian Tindakan Kelas. Jakarta: Universitas Terbuka. 
Wulandari, Gusti Ayu Mirah. 2016. Penerapan Pendekatan Saintifik melalui Mind Mapping untuk Meningkatkan Penguasaan Kompetensi Keterampilan Menulis Bahasa Indonesia Siswa Kelas IVA SD Negeri 29 Pemecutan Tahun Ajaran 2015/2016. Skripsi (tidak diterbitkan). Jurusan Pendidikan Guru Sekolah Dasar, FIP Undiksha.

Wycoff, Joyce. 2005. Menjadi Super Kreatif Melalui Metode PemetaanPikiran. Terjemahan Rina S. Marzuki. Mind Mapping Your Personal Guide to Exploring Creativity and Problem-Solving. Bandung: Kaifa.

Yasin, Sulchan. 2002. Korespondensi Umum Surat- menyurat Praktis Siap Pakai. Surabaya: CV Adis 